\title{
Homenagem ao professor Manoel Lelo Bellotto*
}

Em setembro de 2011, a comunidade acadêmica de São Paulo perdeu um de seus mais legítimos representantes, como professor, pesquisador, gestor, o professor Manoel Lelo Bellotto, que inscreveu uma trajetória de intensa atuação acadêmica, centralizada, em sua maior parte na área das Ciências Humanas, particularmente nos estudos sobre a América Latina. Desde sua formação, como estudante do Curso de História da Universidade de São Paulo, já demonstrava seu interesse pela área que abraçou na construção de sua carreira acadêmica.

Bellotto iniciou sua vida profissional como professor, na condição de docente concursado integrando-se à rede pública de ensino em 1959, atividade que exerceu por quatro anos. Posteriormente, sua contratação como professor de História na Faculdade de Filosofia Ciências e Letras de Presidente Prudente the abriu as portas para outras atividades fazendo surgir o interesse para a pesquisa no desenvolvimento de sua carreira acadêmica. Em 1964 foi contratado pela Faculdade de Filosofia, Ciências e Letras de Assis, onde permaneceu até 1991, ano de sua aposentadoria.

Em várias oportunidades, exerceu a função de diretor em unidades da Unesp (Assis, por duas vezes, Marilia e São Paulo, no Instituto de Artes) participou ainda de órgãos de destaque na Universidade, como por exemplo, da CPRT (Comissão Permanente de Regime de Trabalho), na condição de Presidente sendo responsável por uma nova orientação àquela comissão, principalmente na valorização do Tempo Integral.

Como professor, em Assis, assumiu a condução da disciplina de História da América onde procurou dar continuidade aos ensinamentos adquiridos junto à cadeira de História Moderna e Contemporânea na Universidade de São Paulo. A disciplina esteve estruturada em dois blocos: a História da América Colonial e História da América Independente. Como professor de História da América dedicou a maior parte de suas atividades à América Colonial sendo que, posteriormente, a disciplina de História da América Independente passou a ser exercida por outros docentes.

\footnotetext{
* Por Anna Maria Martinez Corrêa e Beatriz Westin Cerqueira Leite. São Paulo, 27 de junho de 2012.
} 


\section{Homenagem ao professor Manoel Lelo Bellotto}

De acordo com a formação recebida na Universidade de São Paulo onde seus mestres valorizavam a História fundamentada na análise da documentação original, o professor organizou seus ensinamentos como docente e suas pesquisas na busca da documentação em arquivos e bibliotecas do Brasil e do exterior. Construiu assim uma metodologia fundada em fontes informativas para seus cursos e pesquisas, no seu questionamento, na sua organização, análise e interpretação e no levantamento de uma bibliografia de apoio para essas pesquisas. Partiu assim para o levantamento da documentação localizada no Archivo General de Índias (Sevilha), Archivo General de la Nación (Buenos Aires) e Biblioteca Del Museo Naval (Madri). Percorreu ainda outros acervos em Lisboa e em Buenos Aires.

A tarefa da qual se incumbiu, ao ministrar aulas e realizar pesquisas sobre a América Latina veio the demonstrar uma triste realidade, a dificuldade de acesso à informação sobre a História da América. Como seria possível preparar os estudantes para a realização de pesquisas sobre temas latinoamericanos se a área apresentava uma carência tão grande? Parecia uma situação contraditória - se, por um lado havia grande interesse pela América Latina, por outro lado, as informações sobre ela eram ainda muito precárias.

Nesse particular, o professor Manoel Lelo Bellotto desempenhou um papel muito especial, ao reconhecer a fragilidade dos conhecimentos relativos à América Latina no Brasil dos anos 1960/70. Apesar do grande apelo existente entre os estudantes para um conhecimento mais amplo e mais aprofundado do tema, o acesso à documentação era muito difícil. Era uma decorrência do momento histórico já que as referências sobre os países latino-americanos vinham acompanhadas quase sempre pela imagem revolucionária de Cuba. Em tempos de Guerra Fria, de governo militar, as oportunidades de intercâmbio com países da América Latina eram muito limitadas. Daí o empenho do professor, na busca de uma aproximação com outros colegas em encontrar uma solução. A área de estudos sobre América Latina já fora considerada carente pelos próprios encarregados da educação superior pública havendo a necessidade de se incentivar sua dinamização pelas instituições de fomento.

Essa mesma sensação era sentida por colegas da área que chegaram à conclusão de que seria necessário haver uma ação combinada de professores e pesquisadores que pudessem promover um esforço conjunto. A criação de uma associação, por exemplo, para que se pudesse atingir esses objetivos, foi a idéia que surgiu a fim de congregar esforços no sentido de propor alterações nos programas de ensino, no desenvolvimento de publicações, na promoção de eventos acadêmicos, etc. 


\section{História (São Paulo)}

Essas propostas, que eram apenas pontuais, tiveram em Manoel Lelo Bellotto, juntamente com outros pesquisadores uma ação pioneira ao iniciar uma série de publicações sobre o tema. Assim foram efetuadas algumas publicações como a tese de doutorado do professor Bellotto $(\mathrm{O}$ estabelecimento do Correio Marítimo Hispano-americano. 1767-1779), em 1971 e, posteriormente, com uma coletânea de documentos (América Latina de Colonização Espanhola. Antologia de textos históricos), em 1979. Essas propostas não encontraram eco naqueles momentos, mas o professor não desanimou continuando na busca de soluções.

Outra característica marcante da atuação do professor foi como gestor ao dirigir as Faculdades de Assis, Marilia e o Instituto de Artes. Em Assis, sua ação coincidiu com o momento do governo militar (1964 - 1985) que trouxe grandes dificuldades para a administração de um estabelecimento de ensino superior. No entanto, pelas suas qualidades de administrador, o professor conseguiu conduzir com habilidade e diplomacia uma instituição que, além da pressão externa do poder instituído, apoiado pelos setores mais conservadores de uma cidade do interior paulista, contava ainda internamente com a aspiração de estudantes e de professores que ansiavam por mudanças, propondo inovações nem sempre de aceitação unânime. A esses desencontros, o professor procurou responder com equilíbrio, com ponderação, ouvindo todas as partes num entendimento comum. São suas palavras:

Havia alguns campi dos Institutos Isolados que seriam mais conservadores, outros mais contestadores, dentre estes, estava a Faculdade de Ciências e Letras de Assis. Professores e alunos das áreas de Filosofia, Letras, História, das Humanidades em geral, não aceitavam o que ocorria no país do ponto de vista político e institucional. Cabia ao diretor, um papel até certo ponto oneroso e desgastante, por ser, de um lado o porta voz da comunidade universitária junto à direção da CESESP e, por outro lado, por ser o porta voz e executor das determinações superiores junto à unidade universitária junto a alunos e professores. Não foi um momento efetivamente fácil. ${ }^{1}$

Inesquecível foi a iniciativa da realização do festival de Artes de Assis, em 1976.

Juntamente com o professor Álvaro Martins de Andrade, Fernando Cazarin, Sandra Nitrini e outros docentes, o professor Manoel Lelo Bellotto realizou uma das atividades de maior repercussão no

\footnotetext{
${ }^{1}$ Entrevista concedida ao CEDEM - Centro de Documentação e Memória da Unesp -, em 19/03/2002.
} 


\section{Homenagem ao professor Manoel Lelo Bellotto}

campus de Assis promovendo a presença de artistas de renome no campo da música erudita e da música popular, do teatro e outras iniciativas.

Dotado de espírito cordato era também o amigo e companheiro que soube estabelecer uma convivência cordial não apenas com seus colegas de sala de aula ou de locais de pesquisa. Sua relação com os funcionários também se mostrou gentil e responsável pela existência de um clima de amizade e de cordialidade. Basta lembrar as freqüentes confraternizações representadas pelo tradicional jogo de futebol nos períodos de final de aula, ao entardecer, reunindo professores, alunos e funcionários num exercício de profunda amizade.

Manoel Lelo Bellotto mostrou que, além de intelectual integrado à comunidade acadêmica sabia também como conduzir-se diante da cidade, da comunidade local estabelecendo com ela vínculos e relações de amizade. Parece portanto ter atingido a proposta adotada no momento de criação dos Institutos Isolados quando a idéia era de levar a cultura concentrada na metrópole para o interior, de preferência em cidades pequenas que pudessem permitir a tranquiilidade exigida pela produção intelectual. São suas palavras:

Parece-me que a consolidação da Unesp exigiu o que aconteceu até hoje do ponto de vista acadêmico e administrativo na história e na vida dessa universidade. Podemos fazer restrições e ressalvas a procedimentos referentes ao ensino, à pesquisa e à extensão, podemos estar descontentes com os desdobramentos institucionais ou com ações dos mandatários universitários: não importa. Mas eu tenho a impressão de que a consolidação da Unesp implicava realmente nesse caminho que ela pautou até agora. ${ }^{2}$

A aposentadoria do professor em 1991 não significou o fim de suas atividades acadêmicas. Ao contrário sua vida continuou num amplo fluxo de ações compreendendo atividades didáticas, publicações, participação em eventos científicos no país e no exterior.

De sua passagem por Assis e Marilia, fica para nós seus seguidores a memória de uma vida intelectual plenamente vivida, repleta de contribuições para com seus pares deixando apenas o vazio de uma grande saudade.

\footnotetext{
${ }^{2}$ Entrevista concedida ao CEDEM - Centro de Documentação e Memória da Unesp -, em 19/03/2002.
} 